Article

\title{
Regional Differences in Economic Impacts of Power Outages in Finland
}

\author{
Niyazi Gündüz ${ }^{1, *}$, Sinan Küfeoğlu ${ }^{2}$, Christian Winser ${ }^{3}$ and Matti Lehtonen ${ }^{1}$ \\ 1 Affiliation 1; School of Electrical Engineering, Aalto University, Espoo, Finland \\ 2 Affiliation 2; Energy Policy Research Group, University of Cambridge, Cambridge, United Kingdom \\ 3 Affiliation 3; Center for Energy and Environment, School of Management and Law, Zurich University of Applied Sciences, \\ Zurich, Switzerland \\ * Correspondence: niyazi.gunduz@aalto.fi; Tel.: +358-50-301-4377
}

\begin{abstract}
Estimation of the worth of continuity of electricity supply is of interest of industry, authorities and research society. There are numerous methods to calculate the Customer Interruption Costs (CICs). Each method has its advantages and disadvantages. This paper approaches the problem from Distribution System Operators' (DSOs) point of view and adopts two existing analytical models. One model is used by the Finnish Energy Market Authority and the second one was proposed by the authors at a previous study. The model suggested by the authors as an alternative to the one used by the Finnish Energy Market Authority proposes a simple and straightforward methodology which will provide credible and objective estimations by only utilizing publicly available analytical data. We made use of cost and reliability indices data of 78 DSOs in Finland from the year 2016. In addition to cost estimations, this paper highlights regional differences in CIC estimations in different parts of Finland and critically overviews the existing standard customer compensation scheme in Finland.
\end{abstract}

Keywords: customer; interruption; cost; DSO; compensation

\section{Introduction}

The worth of electric power reliability has been a vital question since the liberalisation and unbundling of the electric power systems and markets. Before suggesting further investments in the infrastructure, the planners should know the value of marginal increase power system security and compare it with the cost of interruption events. In addition to this, increasing conscience in consumer rights push authorities for more protective policies. Thus, in some countries such as Finland, Sweden, United Kingdom, the durations of single time outage events are capped and in case of exceeding these allowable limits, the Distribution System Operators (DSOs) are obliged to pay certain compensations back to their customers. Therefore, both the authorities which devise these customer compensation plans and the DSOs which undergo operation and maintenance costs and compensations should be able to understand the true costs of the outage events. Customer Interruption Cost (CIC) estimation methods can mainly be classified as: customer surveys, indirect analytical methods and case studies. Each approach has its own advantages and drawbacks. Customer Surveys are preferred most frequently in literature [1]. They follow Direct Worth (DW), Willingness to Pay (WTP) or Willingness to Accept (WTA) approaches. A customer survey is prepared and sent to the customers by oneto-one interviews, telephone calls, e-mails or by mail. The questionnaires include questions about different power interruption scenarios. Getting customer specific results is the most significant advantage of customer surveys, since the questionnaires can be tailored and they can target industry, service, commercial, residential and agriculture sectors. However, customer surveys demand too much time, labour and money. Moreover, dealing with the subjective responses is another concern. Researchers may end up with high amount of extreme and zero responses at analysis process [2]. Numerous examples for customer surveys can be found in [3]-[6]. Indirect Analytical Methods is the second most preferred CIC estimation approach. Relying on objective data such as electricity prices, value added or turnover of a customer or sector, gross domestic product of a country or annual energy consumption makes indirect analytical methods more favourable if reaching objective results is aimed. They are straightforward, easy to apply, less time, money and labour demanding. However, they tend to yield broad and average results. The studies [7]-[10] are examples for indirect analytical methods. Thirdly, Case Studies can be used to assess CICs. These are done after 
major blackout events. It is regarded as the most reliable CIC estimation method since both direct and indirect economic costs incurred by the power outages are covered through case studies. Nevertheless, large scale blackout events are not seen frequently and carrying out case studies is highly costly, these methods are not common in the literature. Case studies from New York City blackout of 1977 [11] and Storm Gudrun of 2005 in Sweden [12] can be named as successful examples for these. A more comprehensive literature review about the existing studies and a more in-depth assessment of merits and weaknesses of each methodology can be found at [13]. More recent studies can be found based on country specific data. The report [14] summarizes the value of service reliability for the electricity customers in the United States. Another detailed report [15] investigates the value of lost load (VoLL) for electricity customers in Great Britain. The paper [16] presents the worth of Energy not Supplied (ENS) in Scotland. The studies [17] and [18] target the costs of power interruptions at residential sector in the European Union and Italy respectively. Another paper introduces outage cost estimations for industry sector customers from South Korea [19]. Various other generic power interruption assessment papers have been published for customers from Germany [20] Lebanon [21] and South Africa [22]. These studies make use of customer surveys and indirect analytical methods to make the estimations. However, they approach the problem from customer's point of view.

As we can see, majority of the estimation methods are customer centric. The literature on CIC studies from DSO perspective is quite limited. The purpose of this paper is to provide a simple and straightforward analytical approach for the DSOs and regulatory authorities to estimate the electric power interruption costs based on 78 Finnish DSOs' data from 2016. The paper also aims to provide information for the customer protection efforts by comparing the standard compensations and the outage costs estimations. Section 2 presents the methodology where the CIC estimation method used by the Energy Market Authority of Finland [24] and the novel macroeconomic model introduced by [23] are applied. Section 3 includes the results of these approaches obtained through the use of 78 DSO data in Finland from the year 2016. This section also mentions the standard customer compensation scheme applied in Finland. Section 4 concludes the paper with a brief discussion. Appendix includes the detailed results of the calculations as a table. Appendix includes the detailed results of the calculations as a table.

\section{Methodology}

In order to calculate the customer interruption costs experienced in each DSO region, we will make use of two different methodologies. The first one is the formula which is used by the Energy Market Authority of Finland (Energiavirasto) which aims to estimate the total monetary disadvantages caused by long outages according to the formula (1) [24].

$$
C I C_{t, k}=\left(\begin{array}{c}
O D_{\text {unexp }, t} * h_{E, \text { unexp }}+O F_{\text {unexp }, t} * h_{W, \text { unexp }, t}+ \\
O D_{\text {plan }, t} * h_{E, \text { plan }}+O F_{\text {plan }, t} * h_{W, \text { plan }}
\end{array}\right) * \frac{W_{t}}{T_{t}} * \frac{C P I_{k-1}}{C P I_{2004}}
$$

Where;

$C I C_{t, k}:$ monetary worth of the power interruptions to the DSO's customers in year $\mathrm{t}$ in the value of money in year k, (euros)

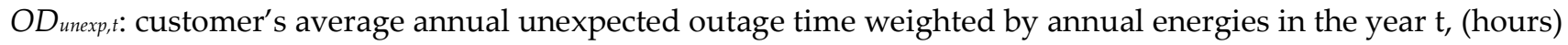

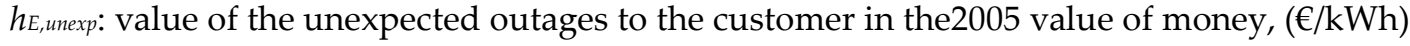

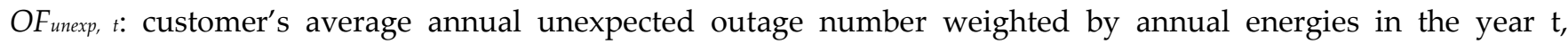
(numbers)

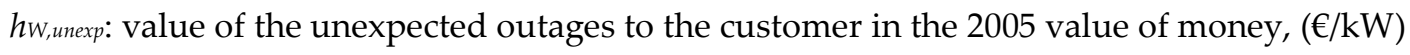

$O D_{\text {plan, }}$ : customer's average annual planned outage timeweighted by annual energies in the year $\mathrm{t}$, (hours)

$h_{E, \text { plan: }}$ value of the planned outages to the customer in the 2005value of money, $(€ / \mathrm{kWh})$

OFplan,: customer's average annual planned outage number weighted by annual energies in the year $\mathrm{t}$, (numbers)

$h_{W, p l a n}$ : value of the planned outages to the customer in the 2005 value of money, $(€ / \mathrm{kW})$

$W_{t}$ : the customer's amount of energy consumption in the year $\mathrm{t},(\mathrm{kWh})$

$T_{t}$ : the number of hours in a year (hours)

CPI: Customer Price Index

The $h$ values are given by the Energy Market Authority and they are shown in Table 1. 
Furthermore, by assuming the CPI of 2005 as 100 in Finland, CPI in 2016 was 120.7 [25].

Table 1. Prices in 2005 Values for Calculation of the Customer Interruption Costs [24]

\begin{tabular}{|c|c|c|c|c|}
\hline coefficient & $\mathbf{h}_{\mathrm{E}, \mathrm{unexp}}(€ / \mathbf{k W h})$ & 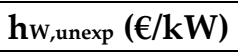 & $\mathbf{h}_{\mathrm{E}, \mathrm{plan}}(€ / \mathbf{k W h})$ & $\mathbf{h w}$,plan $(€ / \mathbf{k W})$ \\
\hline value & 11.0 & 1.1 & 6.8 & 0.5 \\
\hline
\end{tabular}

The second methodology to assess these costs is the macroeconomic approach suggested for the residential customers only [23]. To see the applicability of that approach to the whole customer classes which include industry, service (commercial) and residential ones, we would like to adopt it and then compare the results with the CIC results obtained from formula (1). The theory behind the macroeconomic approach is that one outage-hour during the leisure time corresponds to one hour of less work during working hours and therefore the value of this lost non-working hour is equal to the wage of one hour of work. The details of the macroeconomic approach are as follow:

$$
C I C_{m e}=\mathrm{d} \frac{t w}{\mathrm{PP}}
$$

Where;

$C I C_{m e}$ : the interruption cost estimation via the macroeconomic approach $(€ / \mathrm{kW})$

$t$ : outage duration (hours)

$w$ : average hourly earnings $(€)$

$P P$ : peak power consumption $(\mathrm{kW})$

$d$ : factor for continuous electric power dependency with $d \in[0,1]$.

The study calculates factor $\mathrm{d}$ as:

$$
d=\frac{100 \%-\% \text { of reduction in power consumption }}{100 \%}
$$

In formula (2) peak power is used as a normalization factor. In this paper, we would like to adopt another widely accepted normalization factor, which is the annual energy consumption. By this way, we will be able to compare the results obtained from (1) with the ones from (2). We already presented the data for the annual interruption hours and energy consumption for each DSO. In 2016, the average of total hourly earnings of wage and salary earners was 19.76 $€$ in Finland [26]. Moreover, [23] assumes $d_{\max }$ as 1.0 and $d_{\min }$ as 0.62 . $d_{\max }$ is assumed as 1.0 by implying that the theoretical limit of a customer's dependency to electric power would be $100 \%$, which means the customer would like to use all the electrical appliances without giving consent to a power cut. $d_{m i n}$ is calculated according to the customer survey conducted in Finland. Details regarding to this study could be found at [23]. On the other hand, we should also include the factor that there might be more than one income earner in one electricity customer. According to the Finnish statistical institution, in average there are 1.79 income earners per household in Finland [26]. Therefore, we should modify (2) as:

$$
C I C_{m e}=\mathrm{a} * \mathrm{~d} \frac{t w}{\mathrm{AE}}
$$

Where,

$a$ is the number of average income earners per household $(€)$,

$A E$ is the annual energy consumption (kWh).

\section{Empirical Study and Results}

According to the formula (1), CIC and to formula (4), $C I C_{m e, m a x}$ and $C I C_{m e, m i n}$ have been calculated. The necessary statistical data to calculate the CIC for each DSO, which include the System Average Interruption Duration Index (SAIDI) and the System Average Interruption Frequency Index (SAIFI), as well as the data such as number of customers and energy supplied can be found in [27]. The CIC results are normalized by the annual energy supply per each DSO and then summarized in $€$ cents/kWh in Table A in Appendix. Figure 1 is presented for better understanding the comparison of the outcomes of (1) and (2). 


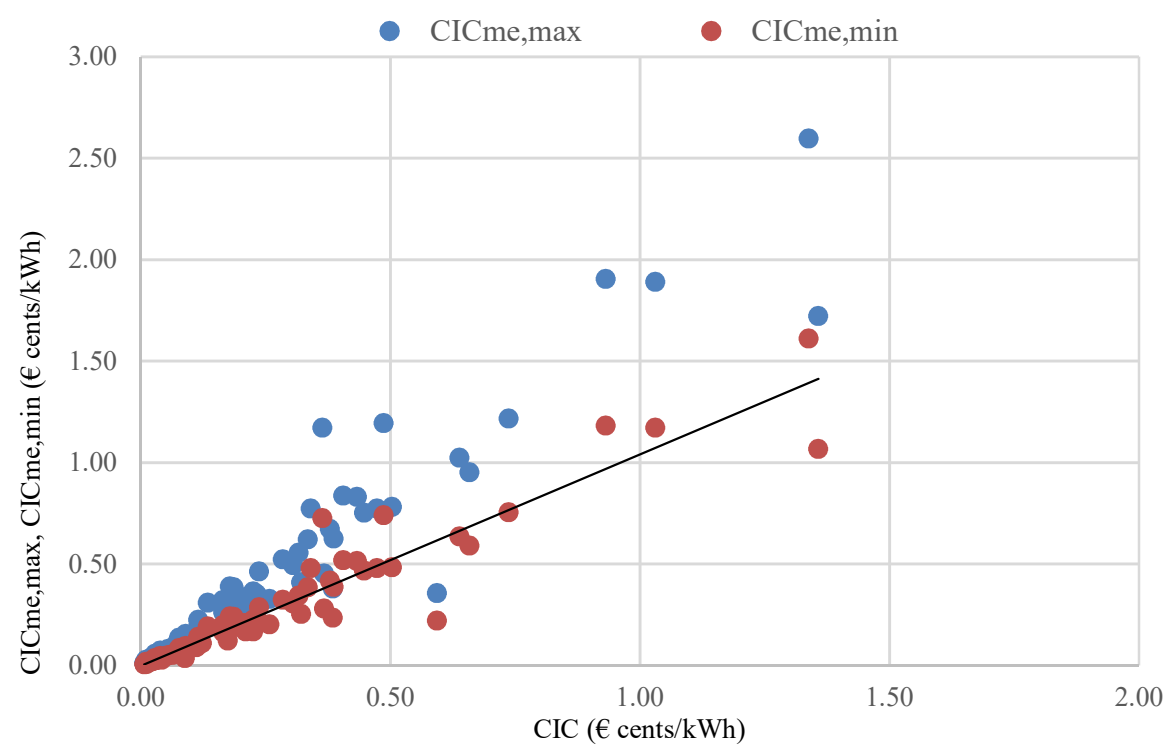

Figure 1. Comparison of $\mathrm{CIC}$ vs. $\mathrm{CIC}$ me, max and $\mathrm{CIC}_{\mathrm{me}, \mathrm{min}}$

From Figure 1 we see that for 78 different DSOs, majority of the results of CIC are closer to $C I C_{m e, m i n}$ than those of CIC me,max. This observation tells us that instead of following (1) which requires extensive data, the novel macroeconomic approach (2) could be used to estimate the total costs of direct and indirect impacts of electric power outages. We should remind that (2) is more simple and straightforward when compared to the methodology used by the Energy Market Authority of Finland. After making this observation, we would like to mention about the customer protection scheme which aims to penalize the DSOs in case of a single outage event lasts longer that the allowable limits. If this limit is exceeded, the DSO is supposed to pay a certain percentage of the annual electricity delivery fee back to the customer. Standard Customer Compensation was accepted in Electricity Market Act in Finland in 2013 [28]. The details are summarized in Table 2 as:

Table 2. Standard Customer Compensation Scheme in Finland, Accepted In 2013

\begin{tabular}{|c|c|}
\hline \multicolumn{2}{|c|}{ Standard Customer Compensation } \\
\hline Outage time (h) & Compensation (\%) \\
\hline $12-24$ & 10 \\
\hline $24-72$ & 25 \\
\hline $72-120$ & 50 \\
\hline $120-192$ & 100 \\
\hline $192-288$ & 150 \\
\hline$>288$ & 200 \\
\hline
\end{tabular}

According to this plan, the maximum amount of compensation to be paid to a customer is to be 1,200 $€$ per year. The purpose of this scheme is to protect electricity consumers from long lasting interruptions and motivate DSOs to provide better and higher quality services to the customers. According to the figures shared by the Energiavirasto in 2016, 7,361,479 € was paid to the customers as compensations [27]. Figure 2 shows the distribution of the amount of compensations per outage duration limits during this period. 


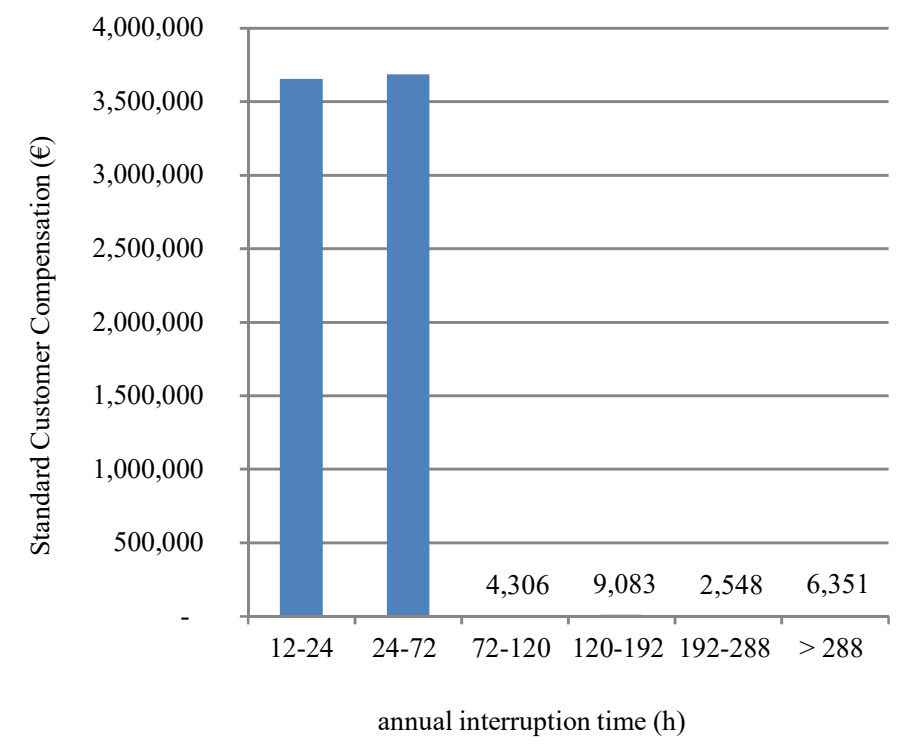

Figure 2. Standard Customer Compensations paid in 2016

As we can see, almost all of the compensations were paid due to the interruption events which took between 12-24 and 24-72 hours. Each period of outage time limit corresponds to around 3.5 million euros, while the other time bands produced compensations less than 10 thousand euros. This means that single outage events that last up to 72 hours pose a threat against the wellbeing of the Finnish consumers since these events are experienced more frequently. Another crucial observation from the analysis is that quite few DSOs paid these compensations in 2016. Out of 78 DSOs, only 32 of those exceeded the allowable limits. Figure 3 shows 24 DSOs which paid standard compensations and the amount of compensation normalized by annual energy supply in 2016. The remaining 8 DSOs were neglected since their normalized figures were quite minimal.

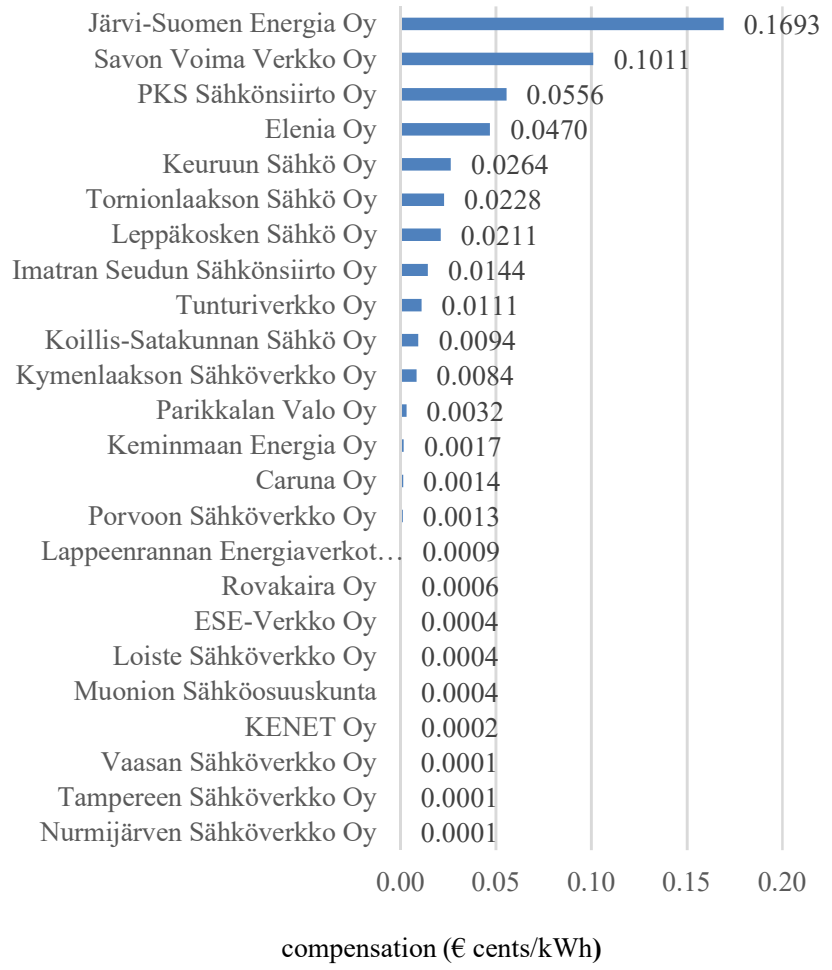

Figure 3. Standard Customer Compensations normalized by the annual energy consumption

Both (1) and (2) could be assessed the indirect analytical methods. By these methods the customer interruption costs are calculated through publicly available and objective analytical data such as number of customers, annual energy 
consumption, gross domestic product, average wages, SAIDI and SAIFI. Nonetheless, to be able to reach customer specific results via these methods is not possible. Extensive customer surveys targeting specific customer groups are necessary for that purpose. The macroeconomic model, $C I C_{m e}(2)$ makes use of national averages of wages, rather than regional averages that each DSO is active in. Figure 4 shows the income distribution in each Finnish region. According to the income figure from 2016, blue regions are above the national average whereas grey ones are below [25].

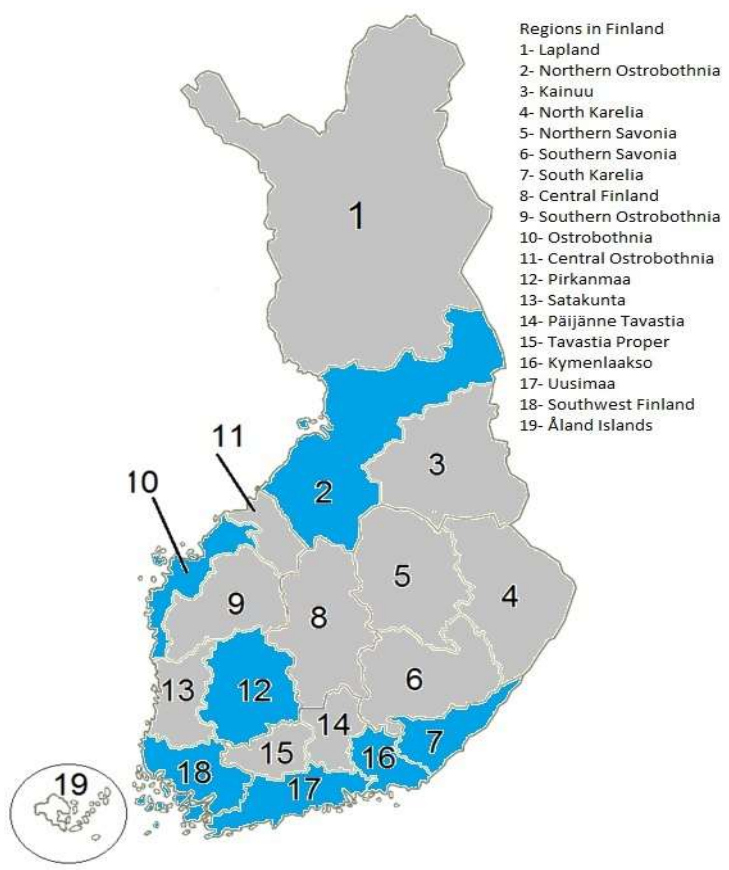

Figure 4. Regional income distribution in Finland in 2016, Blue: above national average, Grey: below national average

One may conclude that since the income level is higher in southern and western Finland, the customer interruption costs per $\mathrm{kWh}$ will be higher as well. In fact, this is not the case. According to our calculations, CIC is higher in northern and eastern parts of Finland and it is the lowest at the southern regions, especially in the Uusimaa region where Helsinki metropolitan area is located. Figure 5 illustrates the lowest and highest CIC regions in Finland in 2016. The share of underground cabling in the distribution network system is crucially important in power reliability. Overhead lines are more prone to external threats than the underground cables. Storms cause substantial damage to the distribution system in Nordic countries. Extreme weather events are the primary causes of power interruptions in countries like Finland and Sweden [29], [30]. When we check reliability figures of Finnish DSOs, we see that there are more frequent and longer lasting outages in rural regions where the distribution distances are longer (Energy Market Authority, 2016). 


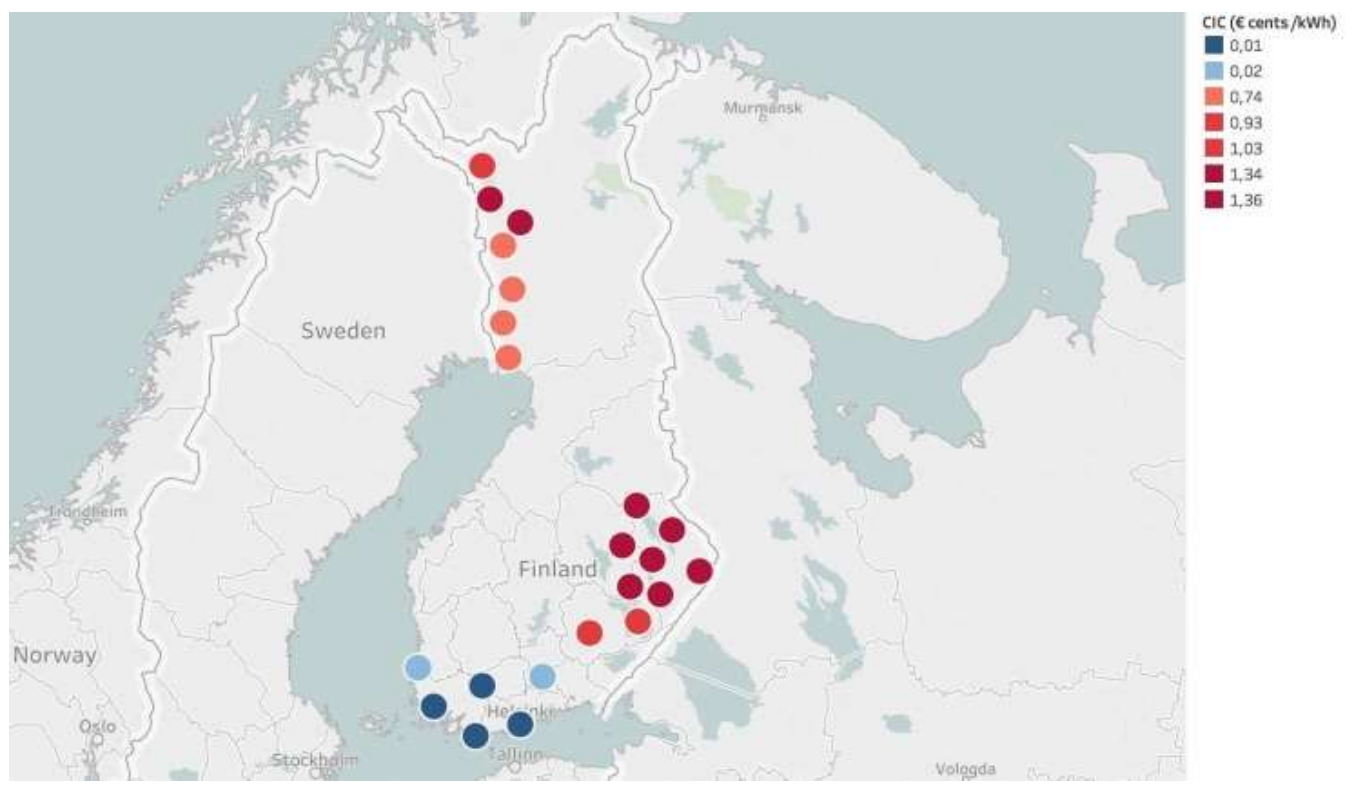

Figure 5. Regional CIC distribution in Finland (€ cents / kWh)

Figure 4 and Figure 5 tell us that there is an inverse proportion between regional level of income and regional CIC in Finland. Therefore, instead of using national average of wages at the macroeconomic model (2), it is imperative to use average wages per each DSO region.

\section{Conclusion \& Discussion}

This paper approaches the customer interruption costs estimations problem from DSO perspective. This study makes use of analytical data shared by 78 Finnish DSOs which provide $99 \%$ of the energy to the low voltage customers in Finland. It is quite crucial to understand the costs of power interruption for planning purposes. Furthermore, protection of customers from long lasting blackouts is another driving factor behind the need of understating the impacts of power outages and their economic worth. Being a popular area of research, there have been numerous studies targeting this problem. However, majority of these studies rely on customer surveys, which are criticized of being biased. Rather than providing a comprehensive review about the CIC phenomena, we focused on a specific case study. This paper presents two existing approaches models and the comparison of the CIC estimations reached via these models. these. As an alternative to the formula (1) used by the Finnish Energy Market Authority, the paper shows that the macroeconomic model (2) can be used by the DSOs to estimate the costs of total direct and indirect impacts of the interruption events in their region in a fast and objective manner. However, it is not possible to get customer specific results through this approach. To understand the value of customer interruptions for industry, service, commercial, residential or agriculture sector, customer surveys are necessary. ${ } I C_{m e}$ will yield average results. However, if regional income levels are used, more customer specific results could be reached. On the other hand, there is evidence that the standard customer compensation plan is not designed in a fair manner. From Figure 3 we see that, while some DSOs paid certain amounts of compensations back to the customers, some did not pay anything at all. This means that the allowable single time outage event time limits should be reconsidered and planned in a way that fair compensations would be paid by the DSOs in case of outage events. Another important observation is that when the CIC results at Table A and Figure 3 are checked, we see that customers are undercompensated in almost all DSO regions. This necessitates that the standard customer compensation scheme in Finland should be revised and a fairer compensation plan should be introduced. 


\section{Appendix A}

Table A. CIC, CIC me,max and CIC me,min per each DSO in 2016 (€ cents / kWh)

\begin{tabular}{|c|c|c|c|c|c|c|c|}
\hline DSO & CIC & CIC me,max & CICme,min & DSO & CIC & CIC me,max $_{\text {max }}$ & CICme,min \\
\hline Äänekosken Energia Oy & 0.12 & 0.23 & 0.14 & Leppäkosken Sähkö Oy & 0.32 & 0.56 & 0.34 \\
\hline Alajärven Sähkö Oy & 0.21 & 0.27 & 0.17 & LE-Sähköverkko Oy & 0.02 & 0.04 & 0.02 \\
\hline Caruna Espoo Oy & 0.23 & 0.36 & 0.23 & Loiste Sähköverkko Oy & 0.18 & 0.39 & 0.24 \\
\hline Caruna Oy & 0.31 & 0.49 & 0.31 & Muonion Sähköosuuskunta & 1.36 & 1.72 & 1.07 \\
\hline Ekenäs Energi $\mathrm{Ab}$ & 0.01 & 0.01 & 0.01 & Naantalin Energia Oy & 0.01 & 0.01 & 0.01 \\
\hline Elenia Oy & 0.47 & 0.77 & 0.48 & Nivos Energia Oy & 0.04 & 0.04 & 0.03 \\
\hline Enontekiön Sähkö Oy & 1.03 & 1.89 & 1.17 & Nurmijärven Sähköverkko Oy & 0.11 & 0.16 & 0.10 \\
\hline ESE-Verkko Oy & 0.03 & 0.06 & 0.04 & Nykarleby Kraftverk Ab & 0.18 & 0.30 & 0.19 \\
\hline Esse Elektro-Kraft Ab & 0.64 & 1.02 & 0.64 & Oulun Energia Siirto ja Jakelu Oy & 0.04 & 0.07 & 0.05 \\
\hline Etelä-Suomen Energia Oy & 0.37 & 0.45 & 0.28 & Oulun Seudun Sähkö Verkko. Oy & 0.12 & 0.20 & 0.12 \\
\hline Forssan Verkkopalvelut Oy & 0.01 & 0.01 & 0.01 & Outokummun Energia Oy & 0.09 & 0.06 & 0.04 \\
\hline Haminan Energia Oy & 0.03 & 0.04 & 0.03 & Paneliankosken Voima Oy & 0.08 & 0.09 & 0.05 \\
\hline $\begin{array}{l}\text { Haukiputaan } \\
\text { Sähköosuuskunta }\end{array}$ & 0.08 & 0.12 & 0.07 & Parikkalan Valo Oy & 0.39 & 0.63 & 0.39 \\
\hline Helen Sähköverkko Oy & 0.01 & 0.03 & 0.02 & PKS Sähkönsiirto Oy & 1.34 & 2.60 & 1.61 \\
\hline Herrfors Nät-Verkko Oy Ab & 0.17 & 0.20 & 0.12 & Pori Energia Sähköverkot Oy & 0.09 & 0.10 & 0.06 \\
\hline Iin Energia Oy & 0.12 & 0.18 & 0.11 & Porvoon Sähköverkko Oy & 0.17 & 0.26 & 0.16 \\
\hline $\begin{array}{l}\text { Imatran Seudun Sähkönsiirto } \\
\text { Oy }\end{array}$ & 0.19 & 0.38 & 0.24 & Raahen Energia Oy & 0.29 & 0.52 & 0.32 \\
\hline Järvi-Suomen Energia Oy & 0.93 & 1.91 & 1.18 & Rantakairan Sähkö Oy & 0.13 & 0.31 & 0.19 \\
\hline Jeppo Kraft Andelslag & 0.59 & 0.36 & 0.22 & Rauman Energia Oy & 0.02 & 0.04 & 0.03 \\
\hline JE-Siirto Oy & 0.03 & 0.04 & 0.03 & Rovakaira Oy & 0.38 & 0.38 & 0.24 \\
\hline Jylhän Sähköosuuskunta & 0.23 & 0.35 & 0.22 & Rovaniemen Verkko Oy & 0.03 & 0.06 & 0.03 \\
\hline Kemin Energia Oy & 0.02 & 0.03 & 0.02 & Sallila Sähkönsiirto Oy & 0.07 & 0.11 & 0.07 \\
\hline Keminmaan Energia Oy & 0.45 & 0.75 & 0.47 & Savon Voima Verkko Oy & 0.66 & 0.95 & 0.59 \\
\hline KENET Oy & 0.06 & 0.08 & 0.05 & Seiverkot Oy & 0.03 & 0.04 & 0.03 \\
\hline Keravan Energia Oy & 0.09 & 0.16 & 0.10 & Tampereen Sähköverkko Oy & 0.03 & 0.06 & 0.03 \\
\hline Keuruun Sähkö Oy & 0.38 & 0.67 & 0.42 & Tenergia Oy & 0.50 & 0.78 & 0.48 \\
\hline Koillis-Lapin Sähkö Oy & 0.49 & 1.20 & 0.74 & Tornion Energia Oy & 0.21 & 0.34 & 0.21 \\
\hline Koillis-Satakunnan Sähkö Oy & 0.41 & 0.84 & 0.52 & Tornionlaakson Sähkö Oy & 0.74 & 1.22 & 0.75 \\
\hline Kokemäen Sähkö Oy & 0.07 & 0.09 & 0.06 & Tunturiverkko Oy & 0.32 & 0.41 & 0.25 \\
\hline Köyliön-Säkylän Sähkö Oy & 0.23 & 0.27 & 0.17 & Turku Energia Sähköverkot Oy & 0.02 & 0.03 & 0.02 \\
\hline Kronoby Elverk Ab & 0.09 & 0.14 & 0.09 & Vaasan Sähköverkko Oy & 0.08 & 0.12 & 0.08 \\
\hline KSS Verkko Oy & 0.08 & 0.14 & 0.09 & Vakka-Suomen Voima Oy & 0.11 & 0.15 & 0.09 \\
\hline Kuopion Sähköverkko Oy & 0.03 & 0.06 & 0.04 & Valkeakosken Energia Oy & 0.06 & 0.08 & 0.05 \\
\hline Kuoreveden Sähkö Oy & 0.06 & 0.09 & 0.05 & Vantaan Energia Sähköverkot Oy & 0.02 & 0.03 & 0.02 \\
\hline $\begin{array}{l}\text { Kymenlaakson Sähköverkko } \\
\text { Oy }\end{array}$ & 0.33 & 0.62 & 0.38 & Vatajankosken Sähkö Oy & 0.18 & 0.30 & 0.19 \\
\hline Lammaisten Energia Oy & 0.05 & 0.07 & 0.05 & Verkko Korpela Oy & 0.26 & 0.33 & 0.20 \\
\hline Lankosken Sähkö Oy & 0.36 & 1.17 & 0.73 & Vetelin Energia Oy & 0.43 & 0.83 & 0.52 \\
\hline $\begin{array}{l}\text { Lappeenrannan Energiaverkot } \\
\text { Oy }\end{array}$ & 0.24 & 0.46 & 0.29 & Vimpelin Voima Oy & 0.16 & 0.32 & 0.20 \\
\hline Lehtimäen Sähkö Oy & 0.34 & 0.77 & 0.48 & & & & \\
\hline
\end{tabular}

\section{Acknowledgements}

The authors would like to acknowledge Fortum Foundation, Espoo, Finland for their funding support through B3 201700083 research grant. 
Author Contributions: N. Gündüz compiled the necessary data and carried out the calculation of the Customer Interruption Costs. He also outlined the regional differences in cost estimations in Finland. S. Küfeoğlu and C. Winzer contributed in the literature review and made the interpretation of the results. $M$. Lehtonen provided general guidance and contributed in the overall quality of the paper.

\section{References}

1. Küfeoğlu, S. and Lehtonen, M., 2016. "A Review on the Theory of Electric Power Reliability Worth and Customer Interruption Costs Assessment Techniques," in 13th International Conference on the European Energy Market (EEM), Porto, Portugal.

2. Küfeoğlu, S. and Lehtonen, M., 2015. "Interruption costs of service sector electricity customers, a hybrid approach," International Journal of Electrical Power \& Energy Systems, vol. 64, pp. 588 - 595, 2015.

3. Kjolle, G.H., Samdal, K., Singh, B. and Kvitastein, O.A., 2008. "Customer costs related to interruptions and voltage problems: Methodology and results," IEEE Transactions on Power Systems, vol. 23, no. 3, pp. 1030-1038.

4. Herman, R. and Gaunt, C.T., 2008. "Direct and Indirect Measurement of Residential and Commercial CIC: Preliminary findings from South African Surveys," in Proc. of the 10th International Conference on Probabilistic Methods Applied to Power Systems, pp. $1-7$.

5. Chowdhury, A.A., Mielnik, T.C., Lawton, L.E., Sullivan, M.J., Katz, A. and Koval, D.O., 2009. "System reliability worth assessment using the customer survey approach," IEEE Transactions on Industry Applications, vol. 45, no. 1, pp. 317-322.

6. Baarsma, B.E. and Hop, J.P., 2009. "Pricing power outages in the Netherlands," Energy, vol. 34, no. 9, pp. $1378-1386$.

7. Hoo, S.Y., 2006. "The causal relationship between electricity consumption and economic growth in the ASEAN countries," Energy Policy, vol. 34, no. 18, pp. 3573-3582.

8. Chen, S.T., Kuo, H.I. and Chen, C.C., 2007. "The relationship between GDP and electricity consumption in 10 Asian countries," Energy Policy, vol. 35, no. 4, pp. 2611-2621.

9. Narayan, P.K. and Prasad, A., 2008. "Electricity consumption- real GDP causality nexus: Evidence from a bootstrapped causality test for 30 OECD countries," Energy Policy, vol. 36, no. 2, pp. 910-918.

10. Cheng, Y.S., Wong, W.K. and Woo, C.K., 2013. "How much have electricity shortages hampered China's GDP growth?" Energy Policy, vol. 55, pp. 369-373.

11. Corwin, J. L. and Miles, W.T., 1978. "Impact Assessment of the 1977 New York City Blackout," U.S. Department of Energy, Washington D.C., US.

12. Carlsson, F., Martinsson, P. and Akay, A., 2008. 'The Effect of Power Outages and Cheap Talk on Willingness to Pay to Reduce Outages," Energy Economics, vol. 30, no. 3, pp. 1232-1245.

13. Küfeoğlu, S. 2015. "Economic impacts of electric power outages and evaluation of customer interruption costs."

14. Sullivan, M. J., Schellenberg, J. and Blundell, M., 2015. "Updated Value of Service Reliability Estimates for Electric Utility Customers in the United States," Ernest Orlando Lawrence Berkeley National Laboratory.

15. London Economics, 2013. Final report for OFGEM and DECC, "The Value of Lost Load (VoLL) for Electricity in Great Britain," London, UK.

16. Poudineh, R. and Jamasb, T., 2017. "Electricity supply interruptions: Sectoral interdependencies and the cost of energy not served for the scottish economy," Energy Journal, vol. 38, no. 1, pp. 51-76.

17. Shivakumar, A., Welsch, M., Taliotis, C., Jakšić, D., Baričević, T., Howells, M., Gupta, S. and Rogner, H., 2017. "Valuing blackouts and lost leisure: Estimating electricity interruption costs for households across the European Union," Energy Research and Social Science, vol. 34, pp. 39-48.

18. Abrate, G., Bruno, C., Erbetta, F., Fraquelli, G. and Lorite-Espejo, A., 2016. "A choice experiment on the willingness of households to accept power outages," Utilities Policy, vol. 43, pp. 151-164.

19. Kim, K. and Cho, Y., 2017. "Estimation of power outage costs in the industrial sector of South Korea," Energy Policy, vol. 101, no. 1, pp. 236-245.

20. Growitsch, C., Malischek, R., Nick, S. and Wetzel, H., 2015. "The Costs of Power Interruptions in Germany: A Regional and Sectoral Analysis," German Economic Review, vol. 16, no. 3, pp. 307-323.

21. Bouri, E. and Assad, J., 2016. "The Lebanese electricity woes: An estimation of the economical costs of power interruptions," Energies, vol. 9, no. 8, pp. 853.

22. Minnaar, U., Visser, W. and Crafford, J., 2017. "An economic model for the cost of electricity service interruption in South Africa," Utilities Policy, vol. 48, pp. 41-50.

23. Küfeoğlu, S. and Lehtonen, M., 2015b. "Comparison of different models for estimating the residential sector customer interruption costs," Electric Power Systems Research, vol. 122, pp. 50-55.

24. Energy Market Authority, 2015. Regulation methods for the assessment of reasonableness in pricing of electricity distribution network operations and high-voltage distribution network operations in the third regulatory period starting on 1 January 2012 and ending on 31 December 2015, [Online]. Available: http://www.energiavirasto.fi/ 
25. Statistics Finland, 2017. Consumer Price Index $2005=100$, [Online]. Available: https://www.stat.fi/

26. Structure of Earnings 2017. Wages, Salaries and Labour Costs 2012, Statistics Finland, [Online]. Available: https://www.stat.fi/

27. Energy Market Authority, 2016. Electricity network figures for 2016, Energy Market Authority of Finland, (Energiavirasto, in Finnish), [Online]. Available: https://www.energiavirasto.fi

28. Electricity Market Act, 2017. (Sähkömarkkinalaki, in Finnish), Ministry of Trade and Industry, Finland, [Online]. Available: http://www.finlex.fi

29. Küfeoğlu, S. and Lehtonen, M., 2014. “Cyclone Dagmar of 2011 and its impacts in Finland," In Innovative Smart Grid Technologies Conference Europe (ISGT-Europe), IEEE PES. pp. 1-6, Istanbul, Turkey.

30. Gündüz, N., Küfeoğlu, S. and Lehtonen, M., 2017. “Impacts of Natural Disasters on Swedish Electric Power Policy: A Case Study," Sustainability, vol. 9, no. 2, pp.230. 